\title{
Pollution Removal Performance of Laboratory Simulations of Sydney's Street Stormwater Biofilters
}

\author{
James Macnamara (1) and Chris Derry* \\ School of Science and Health, Western Sydney University, Penrith 2751, Australia; \\ 16495845@student.westernsydney.edu.au \\ * Correspondence: c.derry@westernsydney.edu.au; Tel.: +61-2-449-631-226
}

Received: 13 September 2017; Accepted: 17 November 2017; Published: 22 November 2017

\begin{abstract}
The City of Sydney is constructing more than 21,000 square metres of street biofilter units (raingardens) in terms of their Decentralised Water Master Plan (DWMP), for improving the quality of stormwater runoff to Port Jackson, the Cooks River, and the historical Botany Bay. Recharge of the Botany Sand Beds aquifer, currently undergoing remediation by extraction of industrial chlorinated hydrocarbon pollutants, is also envisaged. To anticipate the pollution removal efficiency of field biofilter designs, laboratory soil-column simulations were developed by Western Sydney University partnered with the City. Synthetic stormwater containing stoichiometric amounts of high-solubility pollutant salts in deionised water was passed through $104 \mathrm{~mm}$ columns that were layered to simulate monophasic and biphasic field designs. Both designs met the City's improvement targets for total nitrogen (TN) and total phosphorus (TP), with $>65 \%$ median removal efficiency. Prolonged release of total suspended solids (SS) on startup emphasised the need for specifications and testing of proprietary fills. Median removal efficiency for selected heavy metal ecotoxicants was $>75 \%$. The researchers suggested that Zinc be added to the targets as proxy for metals, polycyclic aromatic hydrocarbons (PAH) and oils/greases co-generated during road use. Simulation results suggested that field units will play an important role in meeting regional stormwater improvement targets.
\end{abstract}

Keywords: biofilter; raingarden; stormwater treatment; road runoff; WSUD; soil column

\section{Introduction}

Urban development effectively results in the short-circuiting of the hydrologic cycle, reducing stormwater retention in the terrestrial phase, and limiting natural purification by filtration, settlement, and biochemical stabilisation. Roads receive high-nutrient runoff from yards, parks, and pavements, while vehicles, road infrastructure, and adjacent roofs add metals, polycyclic aromatic hydrocarbons (PAHs), and oils/greases to the mix [1-3].

In Sydney, nutrients and metals in stormwater runoff exert a negative influence on receiving water ecosystems, and are thus the focus of ongoing research and intervention [4-6]. In 2012, the City of Sydney announced their Decentralised Water Master Plan (DWMP) as part of a water sensitive urban design (WSUD) strategy. To implement this, basic stormwater improvement targets, as shown in Table 1, were included in the City's general Development Control Plan (DCP) and Botany Bay Water Quality Improvement Plan (BBWQIP), as approved by the New South Wales (NSW) Office of Environment and Heritage [7,8]. Slight differences in the targets under these two plans relate to informed decision making regarding different environmental needs. 
Table 1. Sydney's stormwater improvement targets.

\begin{tabular}{ccc}
\hline Water Quality Parameter & $\begin{array}{c}\text { Development Control Plan } \\
\text { (DCP) Removal Target }\end{array}$ & $\begin{array}{c}\text { Botany Bay Water Quality Improvement } \\
\text { Plan (BBWQIP) Removal Target }\end{array}$ \\
\hline Total Nitrogen (TN) & $45 \%$ & $45 \%$ \\
Total Phosphorus (TP) & $65 \%$ & $60 \%$ \\
Total Suspended Solids (SS) & $85 \%$ & $80 \%$ \\
Gross Pollutants & $90 \%(>5 \mathrm{~mm})$ & $90 \%(>5 \mathrm{~mm})$ \\
\hline
\end{tabular}

One initiative to implement the plans is the design and construction of 21,000 square meters of decentralised street-biofilter units to intercept and treat stormwater before discharge to receiving waters or the aquifer. A schematic of a basic monophasic biofilter design is shown in Figure 1, although the City use a number of design variations, including an unlined version where aquifer recharge is an aim. A more complex biphasic design involves the addition a 200 to $300 \mathrm{~mm}$ saturation sump to provide an anaerobic environment in which bacteria can carry out denitrification; the conversion of dissolved nutrient nitrogen to harmless atmospheric nitrogen in a carbon-rich environment [9]. This reduces algal and cyanobacterial (blue-green algal) nutrients in the stormwater discharged to receiving waters, with a reduction in eutrophication potential.

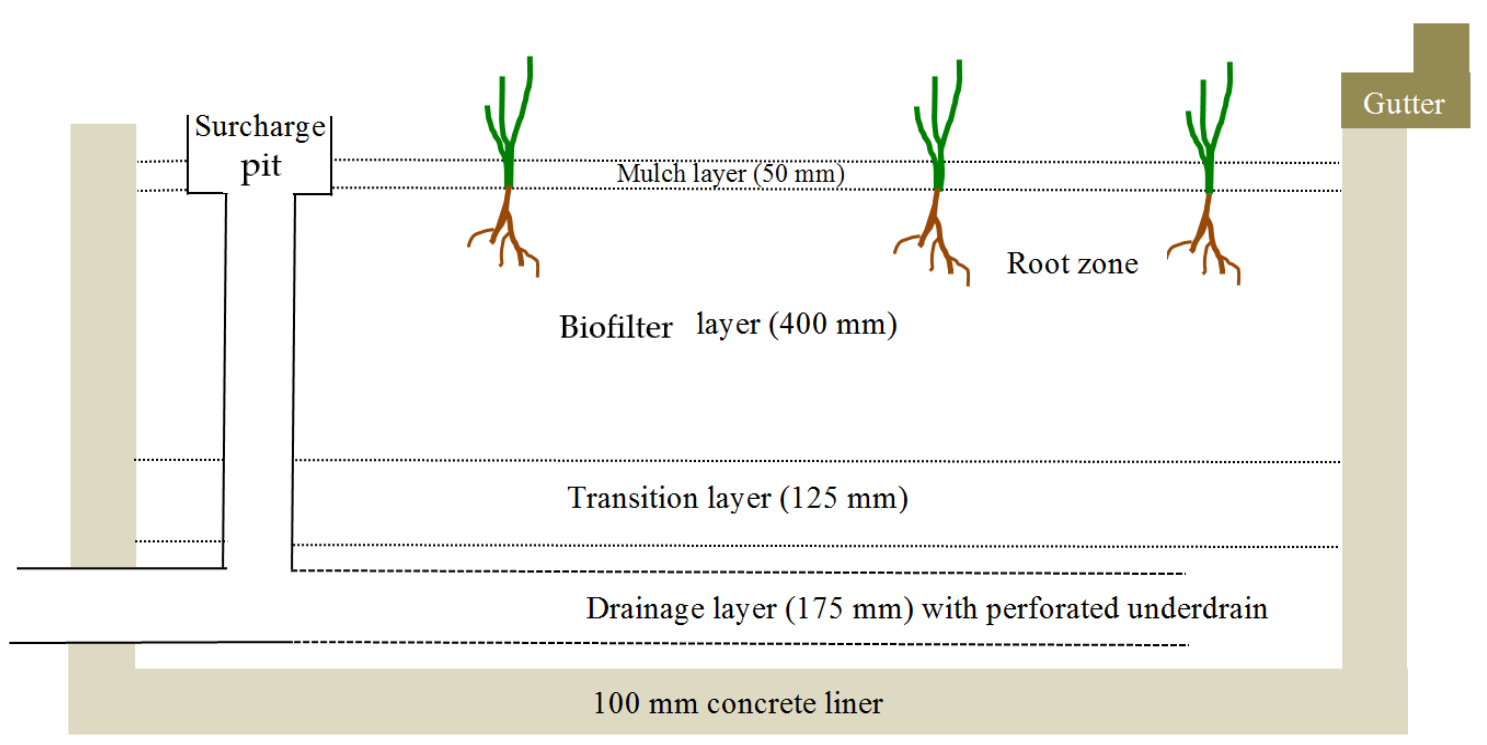

Figure 1. Schematic of a basic lined, monophasic field design showing filter layer depths.

Biofiltration units are often referred to as "raingardens" above the surface because of their ability to visually soften the streetscape with a bed of wetland plants, the active stem, and rootzone, of which maintain surface-layer permeability and provide attachment for nitrifying bacteria (Figure 2).

In 2013, The City of Sydney formed a research partnership with Western Sydney University (WSU) with the aim of conducting laboratory simulations to assess the potential pollutant removal efficiencies of the main field designs under controlled conditions, which is the topic of this paper. A further aim was to guide the development of a performance monitoring framework for the field units, which is a work in progress to be published later.

The use of $104 \mathrm{~mm}$ cylindrical columns facilitated a low-cost and simplified approach using off-the-shelf materials, offering potential for technology transfer to the City, and to urban administrations elsewhere. Given the growing interest in WSUD internationally, the system offered value in terms of the simplified testing of designs and of the available filtration material.

It was agreed that the metric that was applied in the simulation testing would be the regional removal targets, as shown in Table 1, with the addition of heavy metals zinc, copper, nickel, cadmium, 
lead, and chromium, because of their known association with road runoff and their potential ecotoxicity [10-12].

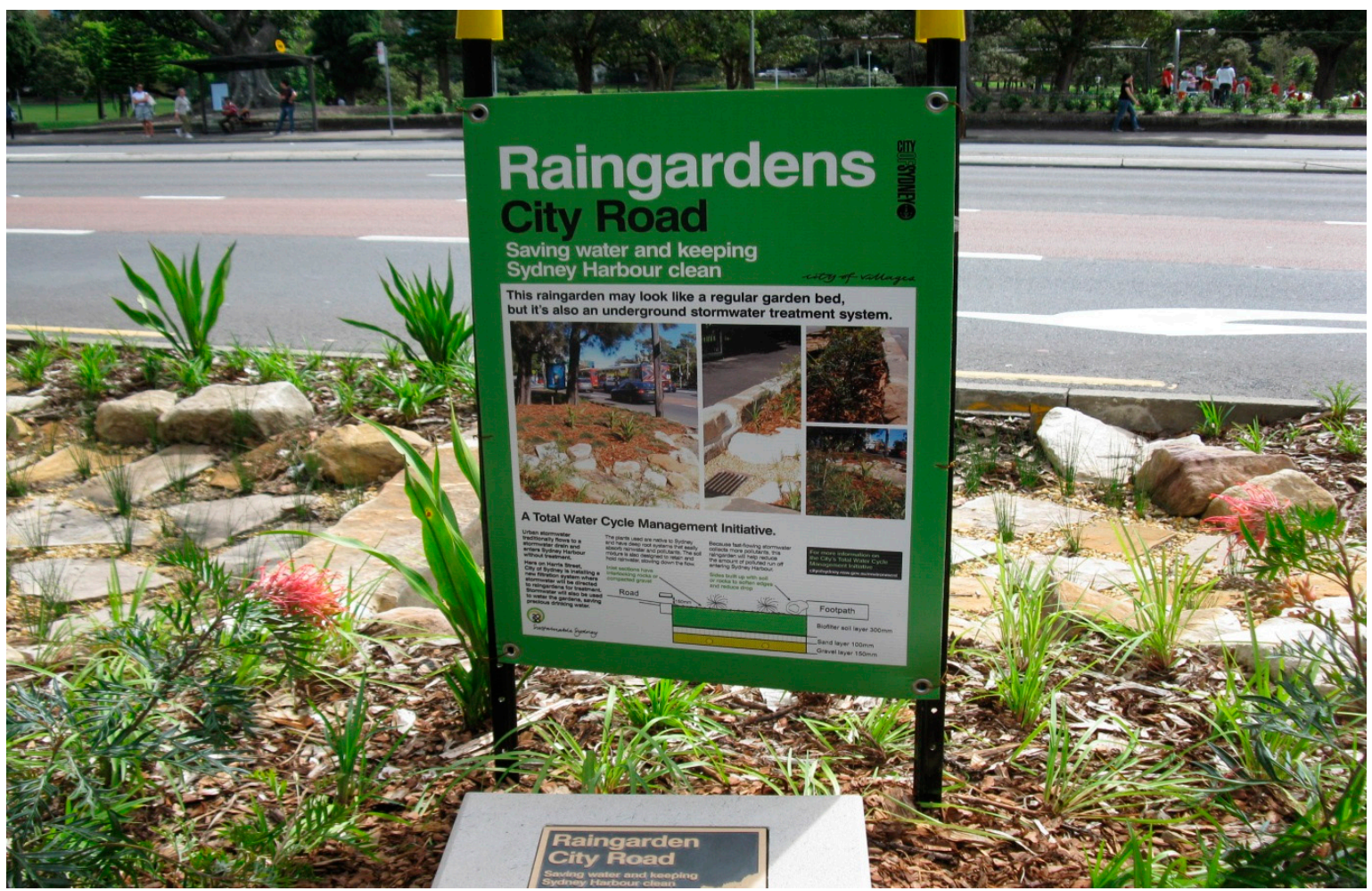

Figure 2. A City of Sydney raingarden.

Heavy metal indicators in road runoff have also been shown to exhibit strong correlation, with hydrocarbon indicators such as BTEXN (benzene, toluene, ethylbenzene, xylenes, and naphthalene), TRH (total recoverable hydrocarbons), and PAH $[13,14]$. This makes highly soluble heavy metals, such as zinc, good proxies for a range of co-generated pollutants in hydraulic column experiments where added non-polar hydrocarbons would coat filter particles, interfering with the removal of important polar pollutants, such as the metals and nutrients. Given these considerations, hydrocarbons were not included in the column simulation experiments, but given their variability and potential ecotoxicity, they will be included in the later field study of biofilter performance.

While total suspended solids (SS) could not be added directly to the synthetic stormwater that was fed to the soil columns for reasons discussed under Section 2.2, SS release on startup from two lots of proprietary raingarden fill material was assessed $[15,16]$. Measurement of gross pollutant (large flotsam) removal was impractical in terms of the size of the material in relationship to the narrow diameter of the columns.

\section{Materials and Methods}

\subsection{Soil Columns}

Soil columns that were identical in vertical section to the field biofilters were established using off-the-shelf $104 \mathrm{~mm}$ diameter PVC tubing, with the aim of producing a cost- and space-efficient experimental unit with a diameter that would limit potential edge effect and dispersivity in the columns.

Edge effect is the tendency for increased hydraulic flow to occur at the interface between a packed column and its retaining surface, resulting in the potential short-circuiting of the column $[17,18]$. 
This effect is likely to be amplified in narrower bore columns because of the increased retaining tube surface area to tube-diameter ratio. To minimize this effect, internal tube surfaces were lightly sanded to retard edge flow, and distribution of the synthetic stormwater took place over a mulch in the centre of the column [19].

In large diameter columns, the risk of dispersivity increases [20]. This involves the erosion of the filter medium itself through the establishment of meandering, lateral flow pathways, which later erode vertically, short-circuiting the filtration medium. Dispersivity is exacerbated by fine particles that are added to the fill to support plant growth, particularly in the presence of excess sodium ions.

All of the columns were established in tandem in terms of a common City of Sydney design where two units are linked by pipework under a central pedestrian access way leading to a safe road crossing point. Simulation of biphasic, lined field units was achieved by arranging the second column inlet $210 \mathrm{~mm}$ above the first column outlet with a $13 \mathrm{~mm}$ diameter link, simulating the inverted siphon arrangement used to maintain the saturation zone in field designs (Figure 3).

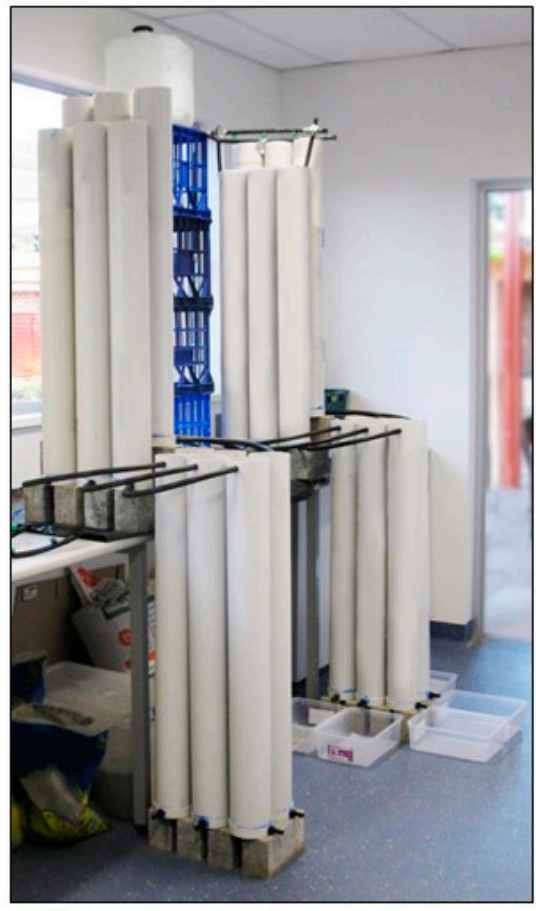

(a)

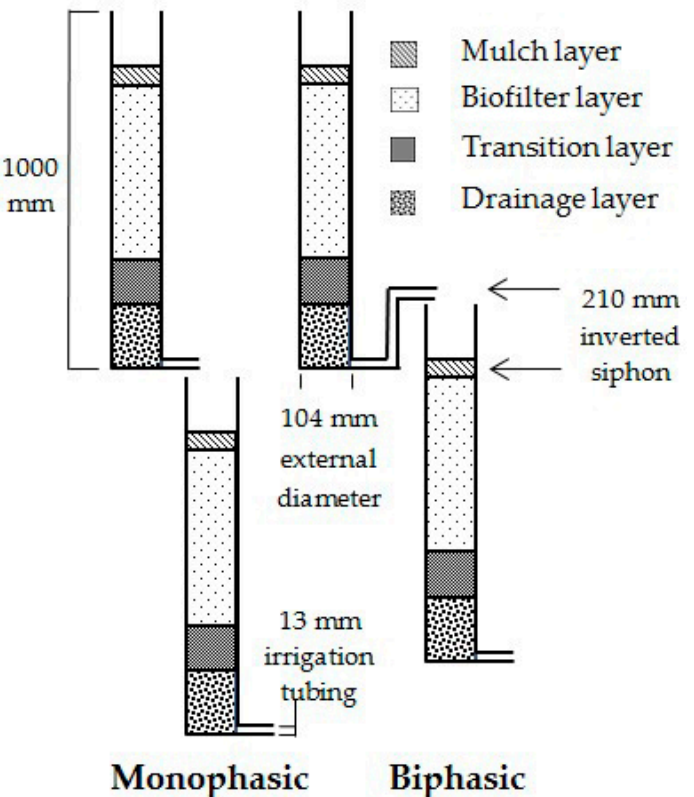

(b)

Figure 3. Laboratory columns: (a) view of general layout; (b) sectional schematic showing arrangement and layering.

While wetland plants and their related root zone are an integral part of field units, planting of the columns to represent the distribution and variety of plants found in raingardens was not feasible, given the small column diameter. This was, however, a scientifically conservative approach in that raingarden plants enhance pollution removal through biochemical activity in the rhizosphere of well-maintained field units [21]. In field settings, plant stem presence and root movement keeps surface channels open, and this was compensated for in the columns by using a distribution pebble-mulch and the avoidance of clogging material in the synthetic stormwater [22,23]. It was assumed that the necessary microorganisms for a range of biochemical processes would be present in the quarry fill media, which was commercially extracted from riverine sources [24].

During each monophasic experiment, synthetic stormwater was conducted from a hard-plastic header tank through an adjustable drip-feed system to the primary column, from which it drained to the secondary column, exiting at the column base for collection and analysis. 


\subsection{Synthetic Stormwater}

The concentration of each pollutant in the synthetic stormwater was based on the median value that was reported for laboratory simulations elsewhere, averaged with the median value for six grab samples for first flush events at Sydney sites where field units were to be constructed [25-30]. It is important to note, that on this basis, synthetic stormwater formulation would vary for each City catchment and that some standardization is ultimately needed [31].

The synthetic stormwater was produced by dissolving stoichiometric amounts of high-solubility salts containing relevant pollutant ions in deionised water, followed by iterations of analysis and adjustment until a stable product complying with the required concentrations was achieved.

Suspended solids were not included in the synthetic stormwater because of the potential for adsorption of the positively charged ammonium and metal ions at an unknown rate onto these particles during storage, and the absence again of research standards relating to particulate size and ion-exchange properties. For this reason, the study followed the direction of a number of published studies in omitting SS from their versions of synthetic stormwater [25,27-30].

In terms of impact on results, the exclusion of SS represents a conservative scientific approach in that SS mobilized by stormwater in Sydney is known to contain a variable proportion of zeolite, which would be likely to improve removal efficiency for cations in the field units [32].

\subsection{Column Performance Experimental Method}

An experimental soil-column method was developed with the following phases:

1. Purging: To limit background column "noise", naturally occurring soluble ions were purged from the soil column using deionised-water flushing until the three-day median for electrical conductivity (EC), a proxy for ion content, fell to $5 \%$ of that of the synthetic stormwater. This typically took eight consecutive days for a fill that is compliant with City of Sydney biofilter material specifications, as discussed later. Post-purge draining for $16 \mathrm{~h}$ resulted in a median mass reduction of $70 \%$ reducing the risk of potential dilution of pollutants in the synthetic stormwater.

2. Dosing: Each primary column was dosed with $1.1 \mathrm{~L}$ of synthetic stormwater per hour based on the unsaturated hydraulic conductivity rate for the soil column, as determined by a Decagon Devices ${ }^{\circledR}$ mini disk portable tension infiltrometer. For each experimental run, dosing was maintained for three hours based on the dosing regime established elsewhere for effective cation capture [25,32], which complied with recorded median rainfall duration for the years 2010 to 2013 [33]. It must be noted that the dosing cycle was based principally on hydraulic and not climatological considerations given the endemically high rainfall variability on the Eastern seaboard relating to the El Nino Southern Oscillation, reducing the reliability of rainfall prediction since the year 2000 [34].

Following dosing, the columns were drained to an inert sampling container for a median interval of $16 \mathrm{~h}$ until all of the drainage ceased, yielding a median $2.3 \mathrm{~L}$ sample. Five days were then allowed to elapse, after which the dosing process was repeated, with a final repeat after five days in compliance with established hydrological principles [35-37]. This dosing process was repeated three times for both monophasic and biphasic designs, with the experiment run in tandem, giving a total of 18 results for each pollutant to provide sufficiently reliable data for analysis.

A conditioning period for the columns as applied by some researchers was considered unnecessary given that the filter material was commercially sourced from riverine quarries where hardy microbial species that were present in wetland ecosystems would be likely to be well represented. Given the organic component of the fill, it was hypothesized that there would be good retention with rapid regrowth [38].

3. Sample removal: A representative aliquot of the water drained from each column during each $19 \mathrm{~h}$ event was bottled for transport and analysis in compliance with Standard Methods [39]. 
In terms of quality control, no significant difference was noted in the level of individual pollutants taken at different stages of the sampling cycle (with the exception of copper), although a risk of dilution of "new" water with "old" water (such as purge) remaining in the biphasic columns has been reported in the literature [40]. Initial high copper release may, however, have been an artefact resulting from the leaching of nutrients and metals from organic material in the columns, offsetting the dilution of pollutants by residual purge water in initial column runs. The amount of water that was retained in the saturation sump wasshown to be $<0.64 \mathrm{~L}$ by experimentation; offering potentially low dilution.

\subsection{Laboratory Analysis, Data Capture and Statistical Analysis}

Analysis of samples was carried out by Australian Laboratory Services (ALS) Environmental, in terms of a City of Sydney policy requirement that all of the environmental samples be sent to laboratories maintaining NATA accreditation. Analysis was performed on each sample for Total Nitrogen (TN) (APHA 4500 Norg/ $\mathrm{NO}_{3}$ method), Total Phosphorus (TP) (APHA 4500 P-F method), and metals cadmium $(\mathrm{Cd})$, chromium $(\mathrm{Cr})$, lead $(\mathrm{Pb})$, nickel $(\mathrm{Ni})$, copper $(\mathrm{Cu})$, and zinc $(\mathrm{Zn})$ (inductively-coupled plasma mass spectrometry (ICP-MS)).

The returned data were saved using Microsoft Excel ${ }^{\circledR}$ and were assessed for parametry for each pollutant by probability plotting using Minitab 18 Express with the application of Anderson-Darling testing for normality at the assumed significance limit $(p=0.05)$. After stripping outliers, data for all of the parameters except copper were found to be normally distributed enabling a two-tailed, heteroscedastic $t$-test to be applied to assess the difference in removal efficiency between monophasic and biphasic units. For visual examination of data spread, box-and-whisker plots were constructed using $\mathbf{R}^{\circledR}$ open source software environment for PC.

\section{Results and Discussion}

Median concentration removal efficiency for each of the synthetic stormwater pollutant parameters for two designs are shown in Table 2, followed by box-and-whisker plots (Figures 4-6) with a discussion of results. In the plots, the box limits containing the median (horizontal bar) represent the interquartile range $\mathrm{Q} 1-\mathrm{Q} 3$, and the whiskers the total range.

Table 2. Pollutant concentrations and removal efficiency by monophasic and biphasic simulations.

\begin{tabular}{ccccccc}
\hline Pollutant & $\begin{array}{c}\text { Source } \\
\text { Parameter }\end{array}$ & $\begin{array}{c}\text { Pollutant } \\
\text { Synthetic } \\
\text { Stormwater }\end{array}$ & $\begin{array}{c}\text { Concentrationin } \\
\text { Synthetic } \\
\text { Stormwater }(\mathbf{m g} / \mathbf{L})\end{array}$ & $\begin{array}{c}\text { Pollutant Concentration } \\
\text { (Median) after } \\
\text { Biofiltration }(\mathbf{m g} / \mathbf{L})\end{array}$ & \multicolumn{2}{c}{$\begin{array}{c}\text { Removal Efficiency } \\
\text { (Median) for Biofiltration } \\
\text { Simulation (\%) }\end{array}$} \\
\cline { 6 - 7 } $\mathbf{T N}$ & $\begin{array}{c}\text { Ammonium, } \\
\text { nickel and lead } \\
\text { nitrates }\end{array}$ & 16.19 & 2.58 & 1.78 & 84.1 & 89.0 \\
\hline $\mathbf{T P}$ & $\begin{array}{c}\text { Mrisodium } \\
\text { phosphate }\end{array}$ & 10.00 & 2.22 & 3.15 & 77.8 & 68.5 \\
\hline $\mathbf{Z n}$ & Zinc chloride & 0.690 & 0.098 & 0.103 & 85.8 & 85.1 \\
\hline $\mathbf{C u}$ & Copper sulphate & 0.140 & 0.044 & 0.042 & 68.6 & 70.0 \\
\hline $\mathbf{N i}$ & Nickel nitrate & 0.070 & 0.006 & 0.008 & 91.4 & 88.6 \\
\hline $\mathbf{C d}$ & $\begin{array}{c}\text { Cadmium } \\
\text { chloride }\end{array}$ & 0.013 & 0.0004 & 0.0003 & 96.9 & 97.7 \\
\hline $\mathbf{P b}$ & Lead nitrate & 0.300 & 0.024 & 0.025 & 92.0 & 91.8 \\
\hline $\mathbf{C r}$ & $\begin{array}{c}\text { Potassium } \\
\text { chromate }\end{array}$ & 0.050 & 0.006 & 0.004 & 88.0 & 92.0 \\
\hline
\end{tabular}




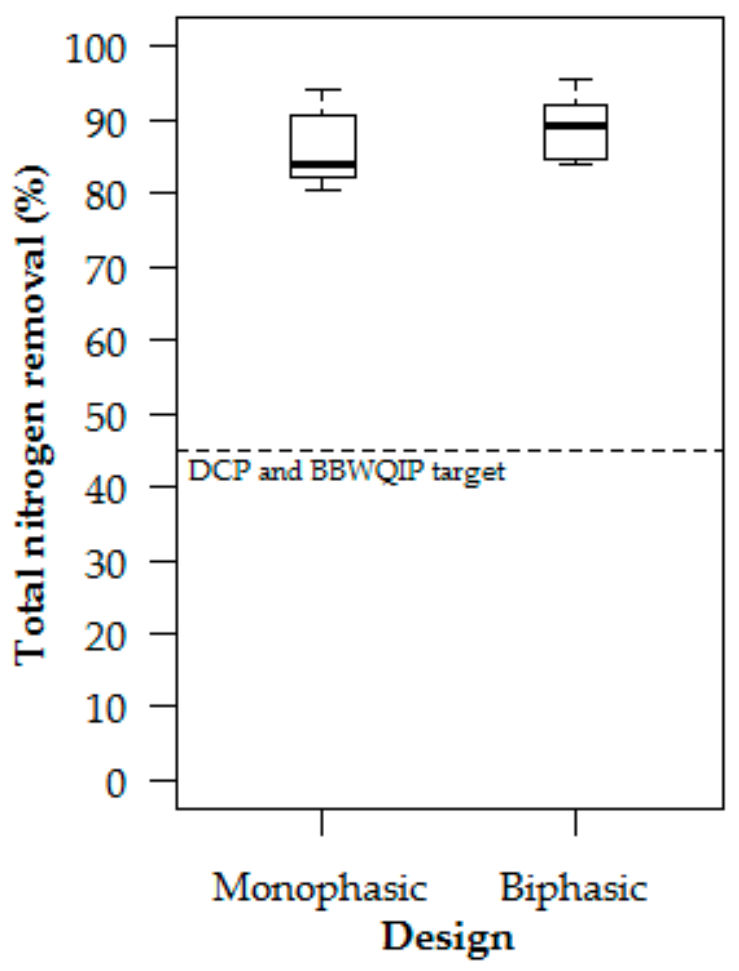

(a)

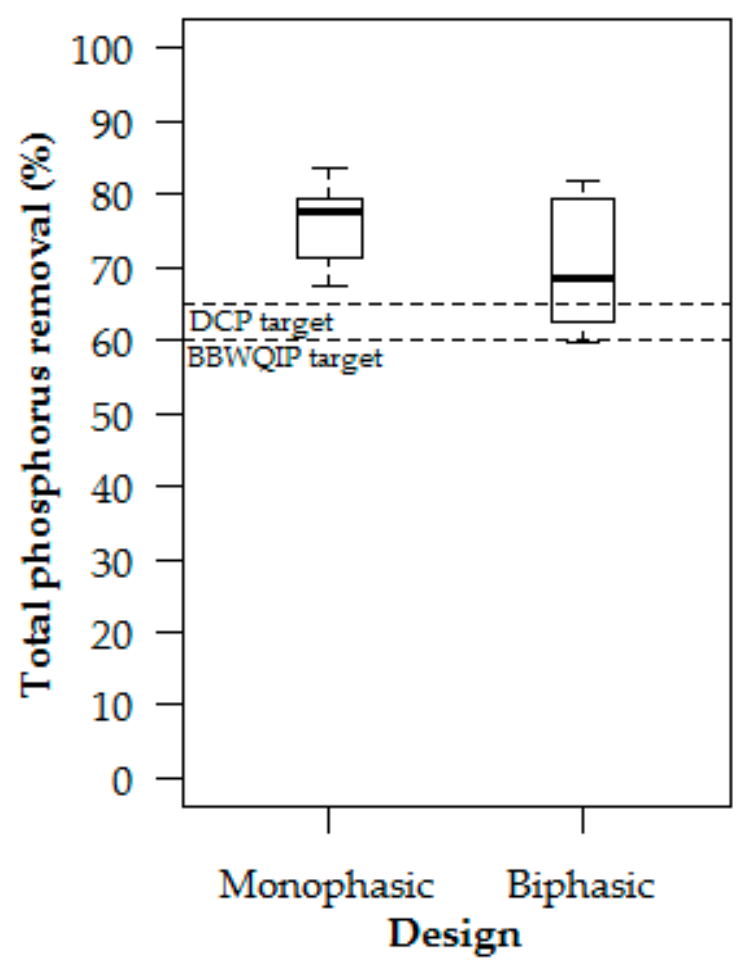

(b)

Figure 4. Median nutrient removal efficiency by design type: (a) total nitrogen (TN); (b) Total phosphorus (TP).

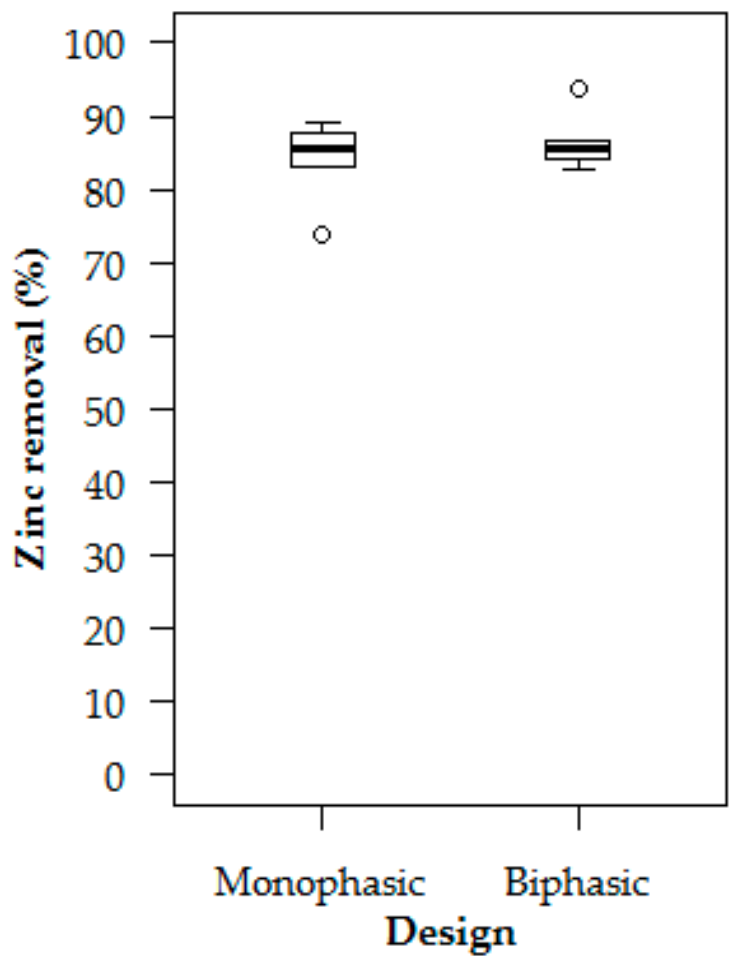

(a)

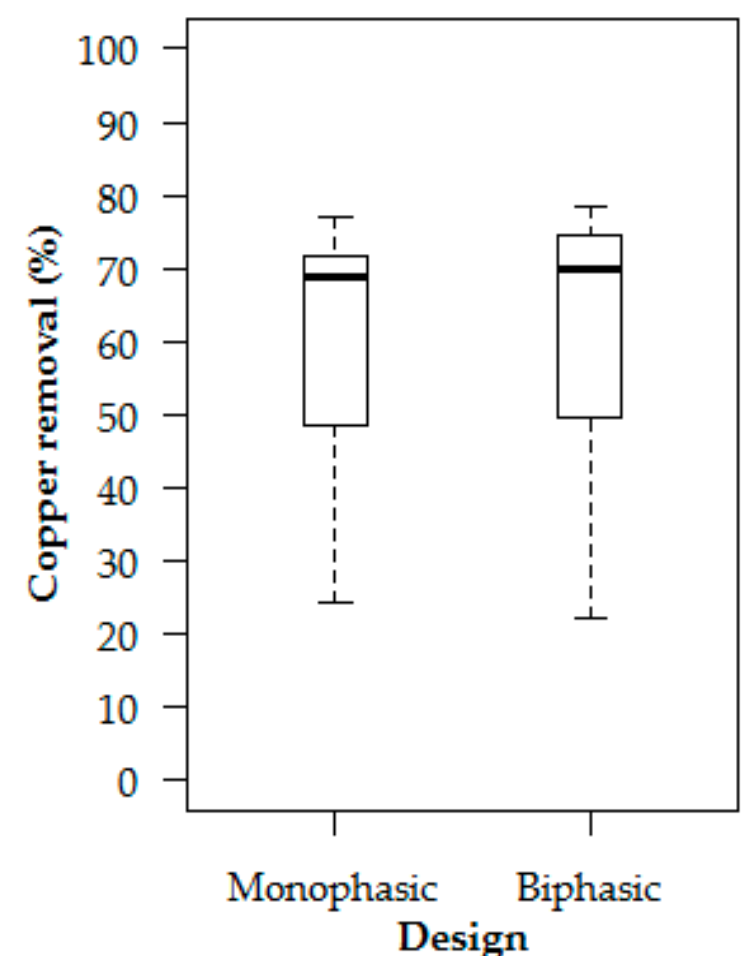

(b)

Figure 5. Cont. 


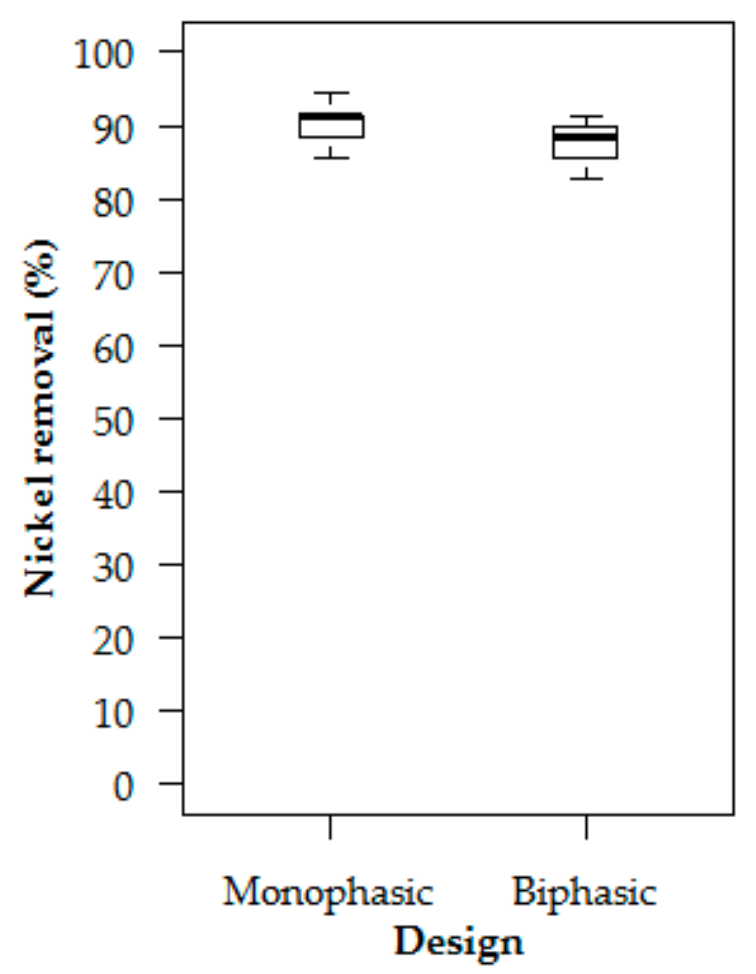

(c)

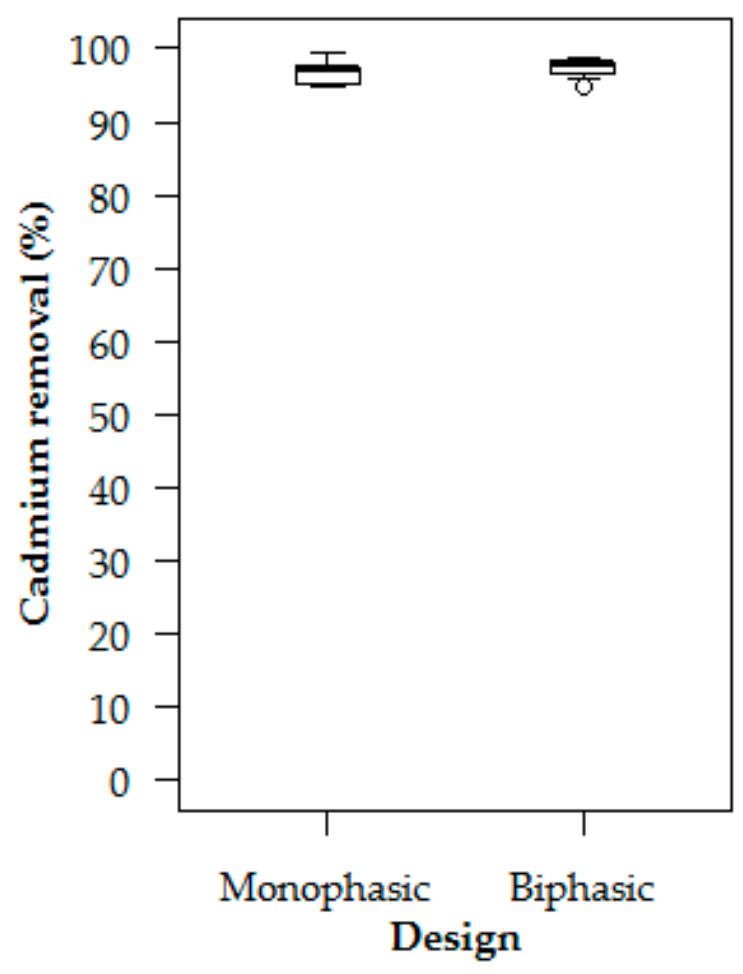

(d)

Figure 5. Dissolved-phase heavy metal removal efficiency by design type: (a) zinc (Zn); (b) copper $(\mathrm{Cu})$; (c) nickel (Ni); and, (d) cadmium (Cd). "o" indicates outlier.

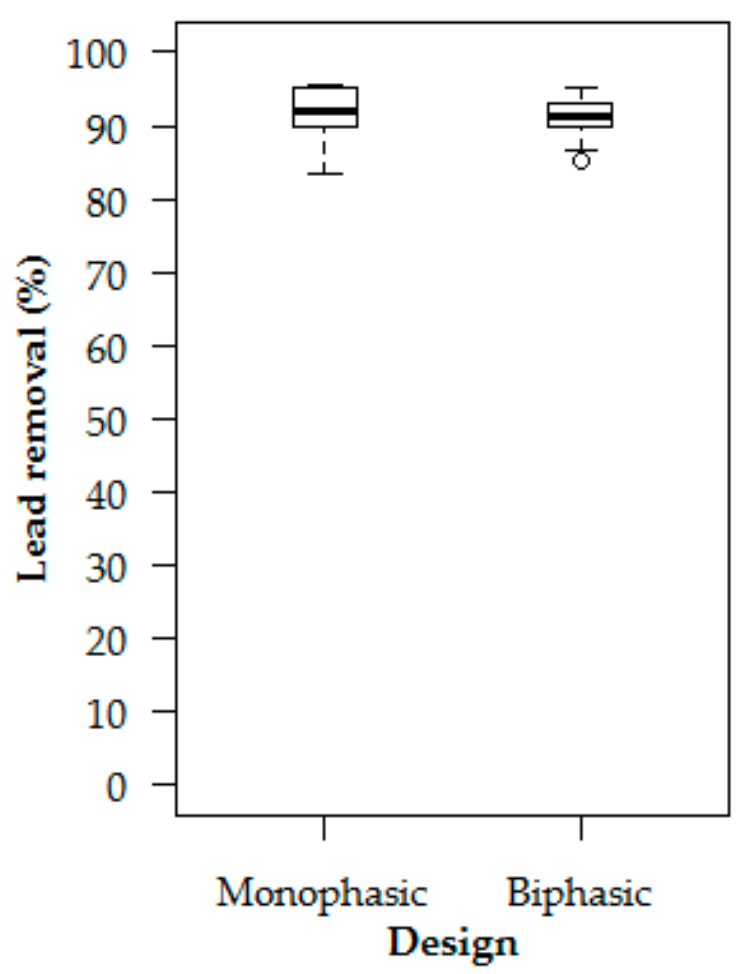

(a)

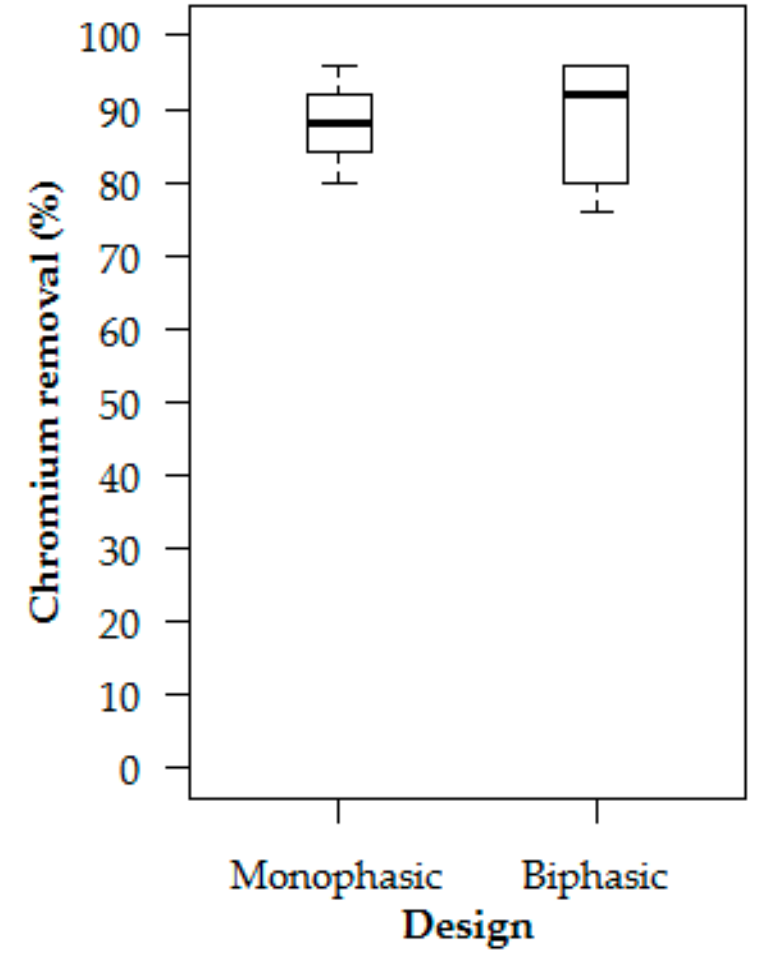

(b)

Figure 6. Suspended- or settled-phase heavy metal removal by design type: (a) lead; (b) chromium. " $\mathrm{O}$ " indicates outlier. 


\subsection{Nutrient Removal: Total Nitrogen (TN) and Total Phosphorus (TP)}

The simulation columns achieved a median $84.1 \%$ and $89.0 \%$ TN removal efficiency for monophasic and biphasic designs, respectively, suggesting the achievement of the DCP and BBWQIP target of $45 \%$ to be well within reach for equivalent field units (Figure 4a). The higher median nitrogen removal efficiency for the biphasic unit suggested that nitrification-denitrification had been initiated, although this was not statistically significant in this short-term simulation. Nitrification-denitrification would be likely to be enhanced in biphasic field units with an established root zone and an elevated dissolved carbon input from road runoff $[41,42]$.

A comprehensive biphasic study elsewhere using rectangular soil columns of a larger crosssectional area $(460 \times 610 \mathrm{~mm})$ achieved very similar TN removal efficiency $(82 \%)$, suggesting the validity of using the economical, narrower-bore design [43].

For TP the median removal efficiencies for the two designs were $77.8 \%$ and $68.5 \%$, respectively, again both complying with the City's DCP and BBWQIP targets (Figure $4 \mathrm{~b}$ ). While the full range of experimental results for the monophasic experiments complied with both targets (range $=67.6 \%$ to $83.8 \%$ ), some of the biphasic results in the interquartile range lay outside of the DCP target. It is possible that this target is too stringent for onsite systems, being based on the performance of centralised water treatment works where chemical coagulation or orthophosphate uptake by biomass ensures a high level of phosphate removal [44]. Further research into the full field-treatment train involving bilfiltration, solids removal through terrestrial settlement and mechanical street sweeping is, however, needed before changing the guidelines.

While biphasic removal efficiency was very similar to that achieved elsewhere by larger rectangular columns $(66 \%)$, it was distinctly better than that achieved elsewhere for small-diameter (64 $\mathrm{mm}$ ) columns (58\% median, $47 \%$ minimum) [45]. It is possible that where the column diameter is reduced below a critical level, factors such as edge effect and biofilm presence exert undue influence on removal efficiency.

Of interest was the increased median removal efficiency of TN, but not of TP, in biphasic as compared to monophasic units. This supports the existence of nitrification-denitrification in the laboratory monophasic units, given that there is no biochemical equivalent for phosphate removal under anaerobic conditions $[38,46]$.

\subsection{Heavy Metal Removal}

The ecotoxicity of metals in stormwater relates in part to their field partitioning in the dissolved, suspended, or settled phase [47]. Predominance in the dissolved phase makes them readily bioavailable and hence more ecotoxic than those in suspended (particulate) or settled (sediment) phases. It must be pointed out, however, that metals readily cross these boundaries depending on the redox or $\mathrm{pH}$ status of the aquatic environment [48]. In making up the synthetic stormwater, metal salts of high solubility were used to ensure availability in the columns.

\subsubsection{Dissolved-Phase Heavy Metals}

Zinc, copper, nickel, and cadmium are the most important dissolved ecotoxicants in stormwater, which, through their bioavailability and bioaccumulation in aquatic and marine food chains, may result in reduction of biodiversity and ultimately the contamination of human water and food supplies [49,50].

Zinc and copper have been shown to exhibit the highest intrinsic ecotoxicity in biomonitoring experiments using representative macroinvertebrates, fish and algae, as based on a number of runoff stages during rainfall events [51]. In terms of intrinsic toxicity $\left(\mathrm{LD}_{50}\right)$, zinc is not as poisonous as the other metals in the dissolved-phase, but occurs in much higher concentrations in road runoff than other heavy metals, making it the most important ecohazard [52]. It is likely to be released by a wide range of road infrastructural sources, including galvanized crash barriers (undergoing frequent gouging impact), fences, traffic light gantries, and street lighting poles, as well as vehicular sources, including 
car bodies, automotive components, and recycled oil. It is an important vulcanising agent in tyres, with deposits being left on the road in rubber globules causing prolonged release, and is leached by soft rainwater from roofs, piping, and other infrastructure in urban areas [2,51].

Given these factors, zinc deserves a high profile in research relating to urban stormwater contamination, whereas copper might be a preferred indicator for atmospheric-mediated stormwater pollution, particularly where smelting of associated heavy metals occurs. Although chromium occurs at relatively low levels within this grouping, the reputation of hexavalent forms as human carcinogens makes it highly relevant in certain industrial settings [52].

In the simulations, median monophasic and biphasic removal efficiencies for metals were impressive, as shown in Figure 5 as read with Table 2. There was, however, no statistically significant difference between median monophasic and biphasic removals. The large interquartile and total ranges for copper may have resulted from copper leaching from biofiltration media in the early part of the experiment based on its known redox-dependent attachment with organic material [53].

The median monophasic removal efficiency results for zinc and copper were extremely similar to results for the field-scale biofiltration simulations that were carried out elsewhere in Australia $(84 \%$ and $67 \%$, respectively); although results are not available in the publication for nickel and cadmium [54].

The current simulation study suggests that the addition of zinc to stormwater improvement targets, as a heavy metal indicator with particular relevance to road runoff, is necessary because of its ecotoxicity and ubiquity. It is not only an animal ecotoxin, but it is highly toxic to plants, including the wetland species that are relied upon to secure hydraulic infiltration and pollutant removal in the raingardens themselves [55]. In this regard, a joint WSU-City of Sydney report implicated the accumulation of zinc in the City's oldest raingardens as being the likely cause of observed leaf stress and dieback of plant cover after about 13 years of street stormwater treatment [8]. Research for identifying the locus of zinc capture in field unit filters would inform strategies for improving the service life, such as the skimming and removal of the surface layer or root zone, or the addition of zeolite or recycled blast furnace slag (BFS) to surface layers [56].

\subsubsection{Suspended- or Settled-Phase Heavy Metals}

Lead and chromium salts on road surfaces are mainly particle-bound, so SS removal by raingardens may be an important strategy in avoiding accumulation of these substances in receiving water sediments [57]. Tetraethyl lead was liberally used (up to $0.15 \mathrm{~g} / \mathrm{L}$ ) as an anti-knock ingredient in Australian petrol from 1921 to 2002, and chromium release still occurs from wear and tear to automotive steel, chromium plating, paints, corrosion coatings, brake linings, and catalytic converters. Certain industrial plating processes act as a potential source of carcinogenic hexavalent chromium compounds, and these could also be environmentally generated through the conversion of the non-carcinogenic trivalent form [52].

In the column simulations impressive median monophasic and biphasic removal efficiencies were again obtained, as shown in Figure 6 as read with Table 2.This represented a reduction of hexavalent chromium in the synthetic stormwater to $<10 \mu \mathrm{g} \mathrm{L}^{-1}$, which, in a field setting, would increase the percentage of aquatic species protected from $80 \%$ to $90 \%$, were treatment of $100 \%$ of receiving water to be achieved [58].

Given the potential for the sudden release of metals from sediments that are subjected to storm scouring or $\mathrm{pH}$ change, and the potential threat to biodiversity in effected rivers and dams, field research relating to suspended- or settled-phase metals is indicated.

\subsection{Total Suspended Solids (SS) Release}

While the addition of suspended particulate matter to the simulated stormwater was not considered to be viable for the reasons discussed, the problem of sometimes prolonged and variable SS release by raingarden filter media on start-up required investigation $[59,60]$. 
Two samples of proprietary filter media (fills) intended for City raingardens were put through purging in $104 \mathrm{~mm}$ monophasic and biphasic columns and the contemporary SS data for each type was pooled. Fill 1 was purchased prior to the implementation of Council's physical-sizing specifications, as shown in Table 3, while Fill 2 was purchased after after implementation.

Table 3. City of Sydney specifications for biofilter material (fill).

\begin{tabular}{cr}
\hline Biofilter Layer and Liner & Specification (Based on FAWB Guidelines [61]) \\
\hline Mulch & Washed aggregate, $10 \mathrm{~mm}$ to $20 \mathrm{~mm}$ grade \\
\hline Filtration & Sandy loam mix, with saturate hydraulic conductivity $>100 \mathrm{~mm} / \mathrm{h}$ to $300 \mathrm{~mm} / \mathrm{h}$. \\
& Total clay and silt content $<3 \%$. Organic content $<5 \%$ \\
\hline Transitional & Washed, recycled glass-sand, or coarse washed river sand with little or no fines \\
\hline Drainage & No-fines drainage gravel, $2 \mathrm{~mm}$ to $5 \mathrm{~mm}$ grade \\
\hline Outer liner & Concrete \\
\hline
\end{tabular}

For both of the fills, the final SS level that was achieved was significantly different from the original level ( $p<0.01$ ), but nevertheless remained above the ecological trigger value of $<50$ NTU (equivalent here to an SS of 78.3) within a week of startup (Figure 7) [58]. Of particular concern was the persistence and variation in SS release for Fill 1 as compared to Fill 2, suggesting that even if low absolute SS levels were achieved at startup, the matrix might remain unstable. A basic soil examination of the fills suggested that instability might have resulted from low particulate traction based on the high smooth-to-sharp fines ratio in the mix, as a result of the inclusion of river-dredged sand.

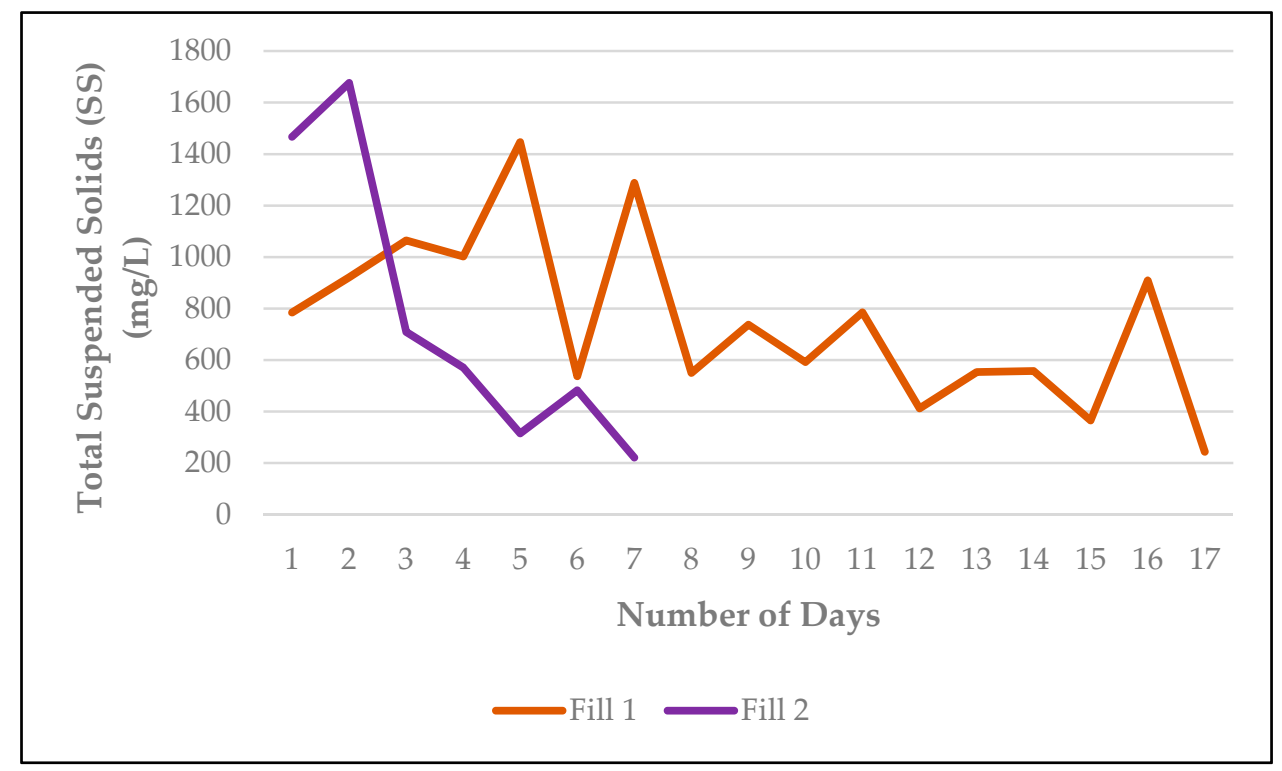

Figure 7. Mean total suspended solids (SS) release from two fills during daily purging.

While the table provides a good starting point for fill material selection based largely on physical considerations, there are also chemical properties to be taken into account, zeolite content enhancing cation retention, sodicity aggravating clogging, and compost introducing unknown chemical factors [62]. Given the difficulty of establishing a metric for chemical content, the authors suggest that it would be expedient to carry out empirical performance testing on all proprietary fills that are intended for large-scale projects, using the cost-effective methods that are described in this paper. 


\section{Conclusions}

The laboratory simulation provided a low-cost, feasible approach for assessing the City of Sydney's biofiltration designs and intended fill material in terms of a limited but locally-relevant set of monitoring parameters. This approach is currently being extended to an additional six local authorities in the Sydney Metropolitan region where further field biofilters are being constructed in terms of the Cook's River Alliance initiative.

Removal of TN by the simulation units was found to be highly efficient, with the results of all test runs showing compliance with the City's targets. The removal of TP by the units was less efficient with a few biphasic test runs failing to comply, although the median results for both monophasic and biphasic designs showed compliance. It is possible, however, that the target for onsite TP removal has been set too high, but this will only be confirmed following research of field units and the treatment train of which they are an integral part.

More than $75 \%$ of heavy metals were removed with the exception of copper, which may have been leached from organic matter in the fill material, as recorded elsewhere. Of particular relevance was the removal of more than $80 \%$ of zinc as an important metallic ecotoxicant in terms of the large quantity generated and its intrinsic ecotoxicity. Given its potential use as proxy for heavy metals, PAHs and oils/greases that are co-generated during road use, the authors have suggested that zinc be added to existing improvement targets, which in NSW typically identify nutrients but not toxicants.

Removal efficiencies for nutrients and metals by the simulations are likely to have been conservative in terms of that which might be obtained in the field, using fully functional planted units within a treatment train that includes mechanical street sweeping and passive stormwater retention structures.

The research supported concerns that excessive and variable SS release from biofilters occurs on startup, but suggested that this can be limited in duration through the rigorous application of basic physical specifications for fills, backed up with low-cost simulation testing, possibly as an in-house activity.

The use of street biofilters remains an important strategy in achieving stormwater quality improvement, with simplified laboratory simulations providing a means for anticipating the potential performance of field designs and quality of intended fill material.

Acknowledgments: The authors wish to acknowledge the funding of the project in terms of a Western Sydney University/City of Sydney research partnership grant.

Author Contributions: Both authors designed the study. James Macnamara designed, built and operated the simulation columns, compounded and sampled the synthetic stormwater, and analysed and presented the data; Chris Derry supervised the research, advised on interpretation of the data and wrote the paper.

Conflicts of Interest: The authors declare no conflict of interest.

\section{References}

1. Todeschini, S. Hydrologic and environmental impacts of imperviousness in an industrial catchment of northern Italy. J. Hydrol. Eng. 2016, 21, 05016013. [CrossRef]

2. Yuan, Q.; Guerra, H.B.; Kim, Y. An investigation of the relationships between rainfall conditions and pollutant wash-off from the paved road. Water 2017, 9, 232. [CrossRef]

3. Al Ali, S.; Debade, X.; Chebbo, G.; Béchet, B.; Bonhomme, C. Contribution of atmospheric dry deposition to stormwater loads for PAHs and trace metals in a small and highly trafficked urban road catchment. Environ. Sci. Pollut. Res. 2017, 1-16. [CrossRef] [PubMed]

4. Spooner, D.R.; Maher, W.A.; Otway, N. Trace metal concentrations in sediments and oysters of Botany Bay, NSW, Australia. Arch. Environ. Contam. Toxicol. 2003, 45, 92-101. [CrossRef] [PubMed]

5. Birch, G.F.; Cruickshank, B.; Davis, B. Modelling nutrient loads to Sydney estuary (Australia). Environ. Monit. Assess. 2010, 167, 333-348. [CrossRef] [PubMed] 
6. Nath, B.; Chaudhuri, P.; Birch, G. Assessment of biotic response to heavy metal contamination in Avicennia marina mangrove ecosystems in Sydney Estuary, Australia. Ecotoxicol. Environ. Saf. 2014, 107, 284-290. [CrossRef] [PubMed]

7. City of Sydney Council. Decentralised Water Master Plan 2012-2030; City of Sydney Council: Sydney, Australia, 2012.

8. Derry, C.; Macnamara, J.W.; Davis, K. A Performance Monitoring Framework for Raingardens as Decentralised Stormwater Treatment Systems in the City of Sydney; University of Western Sydney: Richmond, Australia, 2013.

9. Zinger, Y.; Blecken, G.-T.; Fletcher, T.D.; Viklander, M.; Deletić, A. Optimising nitrogen removal in existing stormwater biofilters: Benefits and tradeoffs of a retrofitted saturated zone. Ecol. Eng. 2013, 51, 75-82. [CrossRef]

10. Maltby, L.; Forrow, D.M.; Boxall, A.; Calow, P.; Betton, C.I. The effects of motorway runoff on freshwater ecosystems: 1. Field study. Environ. Toxicol. Chem. 1995, 14, 1079-1092. [CrossRef]

11. Gillis, P.L. Cumulative impacts of urban runoff and municipal wastewater effluents on wild freshwater mussels (lasmigona costata). Sci. Total Environ. 2012, 431, 348-356. [CrossRef] [PubMed]

12. Zhang, J.; Hua, P.; Krebs, P. Influences of land use and antecedent dry-weather period on pollution level and ecological risk of heavy metals in road-deposited sediment. Environ. Pollut. 2017, 228, 158-168. [CrossRef] [PubMed]

13. Lau, S.-L.; Han, Y.; Kang, J.-H.; Kayhanian, M.; Stenstrom, M.K. Characteristics of highway stormwater runoff in los angeles: Metals and polycyclic aromatic hydrocarbons. Water Environ. Res. 2009, 81, 308-318. [CrossRef] [PubMed]

14. Markiewicz, A.; Björklund, K.; Eriksson, E.; Kalmykova, Y.; Strömvall, A.-M.; Siopi, A. Emissions of organic pollutants from traffic and roads: Priority pollutants selection and substance flow analysis. Sci. Total Environ. 2017, 580, 1162-1174. [CrossRef] [PubMed]

15. Gunawardana, C.; Goonetilleke, A.; Egodawatta, P.; Dawes, L.; Kokot, S. Role of solids in heavy metals buildup on urban road surfaces. J. Environ. Eng. 2012, 138, 490-498. [CrossRef]

16. Liu, X.M.; Li, H.; Li, R.; Tian, R.; Hou, J. A new model for cation exchange equilibrium considering the electrostatic field of charged particles. J. Soils Sediments 2012, 12, 1019-1029. [CrossRef]

17. Cameron, K.C.; Harrison, D.F.; Smith, N.P.; McLay, D.A. A method to prevent edge-flow in undisturbed soil cores and lysimeters. Aust. J. Soil Res. 1990, 28, 879-886. [CrossRef]

18. Brown, R.A.; Hunt, W.F. Impacts of media depth on effluent water quality and hydrologic performance of undersized bioretention cells. J. Irrig. Drain. Eng. 2011, 137, 132-143. [CrossRef]

19. Corwin, D.L. Evaluation of a simple lysimeter-design modification to minimize sidewall flow. J. Contam. Hydrol. 2000, 42, 35-49. [CrossRef]

20. Lewis, J.; Sjöstrom, J. Optimizing the experimental design of soil columns in saturated and unsaturated transport experiments. J. Contam. Hydrol. 2010, 115, 1-13. [CrossRef] [PubMed]

21. Gude, V.G.; Truax, D.D.; Magbanua, B.S. Natural treatment and onsite processes. Water Environ. Res. 2013, 85, 1232-1261. [CrossRef]

22. Read, J.; Fletcher, T.D.; Wevill, T.; Deletic, A. Plant traits that enhance pollutant removal from stormwater in biofiltration systems. Int. J. Phytoremediat. 2010, 12, 34-53. [CrossRef]

23. Virahsawmy, H.K.; Stewardson, M.J.; Vietz, G.; Fletcher, T.D. Factors that affect the hydraulic performance of raingardens: Implications for design and maintenance. Water Sci. Technol. 2014, 69, 982-988. [CrossRef] [PubMed]

24. Hurst, C.J.; Crawford, R.L.; Garland, J.L.; Lipson, D.A. Manual of Environmental Microbiology, 3rd ed.; American Society for Microbiology Press: Washington, DC, USA, 2007.

25. Yang, H.; McCoy, E.L.; Grewal, P.S.; Dick, W.A. Dissolved nutrients and atrazine removal by column-scale monophasic and biphasic rain garden model systems. Chemosphere 2010, 80, 929-934. [CrossRef] [PubMed]

26. Read, J.; Wevill, T.; Fletcher, T.; Deletic, A. Variation among plant species in pollutant removal from stormwater in biofiltration systems. Water Res. 2008, 42, 893-902. [CrossRef] [PubMed]

27. Wan, Z.; Li, T.; Shi, Z. A layered bioretention system for inhibiting nitrate and organic matters leaching. Ecol. Eng. 2017, 107, 233-238. [CrossRef]

28. Davis, A.P.; Shokouhian, M.; Sharma, H.; Minami, C. Water quality improvement through bioretention media: Nitrogen and phosphorus removal. Water Environ. Res. 2006, 78, 284-293. [CrossRef] [PubMed] 
29. Sun, X.; Davis, P. Heavy metal fates in laboratory bioretention systems. Chemosphere 2007, 66, 1601-1609. [CrossRef] [PubMed]

30. Henderson, C.; Greenway, M.; Phillips, I. Removal of dissolved nitrogen, phosphorus and carbon from stormwater by biofiltration mesocosms. Water Sci. Technol. 2007, 55, 183-191. [CrossRef] [PubMed]

31. Davis, A.P.; Shokouhian, M.; Minami, C.; Winogradoff, D. Water quality improvement through bioretention: Lead, copper, and zinc removal. Water Environ. Res. 2003, 75, 73-82. [CrossRef] [PubMed]

32. Birch, G.F.; Fazeli, M.S.; Matthai, C. Efficiency of an infliltration basin in removing contaminants from urban stormwater. Environ. Monit. Assess. 2005, 101, 23-38. [PubMed]

33. Bureau of Meteorology. Daily Rainfall Data for Observatory Hill, Sydney Town, Period 3 February 2010 to 29 January 2013; Bureau of Meteorology: Melbourne, Australia, 2015.

34. Attwater, R.; Anderson, L.; Derry, C. Agricultural risk management of a peri-urban water recycling scheme to meet mixed land-use needs. Agric. Water Manag. 2016, 176, 266-269. [CrossRef]

35. Rusciano, G.M.; Obropta, C.C. Bioretention Column Study: Fecal Coliform and Total Suspended Solids Reductions. Am. Soc. Agric. Biol. Eng. 2007, 50, 1261-1269. [CrossRef]

36. Davis, A.P.; Shokouhian, M.; Sharma, H.; Minami, C. Laboratory study of biological retention for urban stormwater management. Water Environ. Res. 2001, 73, 5-14. [CrossRef] [PubMed]

37. Vanderlinden, K.; Giráldez, J.V. Field Water Capacity. In Encyclo of Agrophys; Gliński, J., Horabik, J., Lipiec, J., Eds.; Springer: Dordrecht, The Netherlands, 2011.

38. Pelissari, C.; Guivernau, M.; Viñas, M.; de Souza, S.S.; Sezerino, P.H.; Ávila, C.; García, J. Unraveling the active microbial populations involved in nitrogen utilization in a vertical subsurface flow constructed wetland treating urban wastewater. Sci. Total Environ. 2017, 584-585, 642-650. [CrossRef] [PubMed]

39. American Public Health Association; American Water Works Association; Water Environment Federation. Standard Methods for the Examination of Water and Wastewater; American Public Health Association: Washington, DC, USA, 2005; Volume 2.

40. Payne, E.G.I.; Pham, T.; Cook, P.L.M.; Fletcher, T.D.; Hatt, B.E.; Deletic, A. Biofilter design for effective nitrogen removal from stormwater-Influence of plant species, inflow hydrology and use of a saturated zone. Water Sci. Technol. 2014, 69, 1312-1319. [CrossRef] [PubMed]

41. Björklund, K.; Li, L. Removal of organic contaminants in bioretention medium amended with activated carbon from sewage sludge. Environ. Sci. Pollut. Res. 2017, 24, 19167-19180. [CrossRef] [PubMed]

42. Stouthamer, A.H.; de Boer, A.P.N.; van der Oost, J.; van Spanning, R.J.M. Emerging principles of inorganic nitrogen metabolism in paracoccus denitrificans and related bacteria. Anton. Leeuwenhoek 1997, 71, $33-41$. [CrossRef]

43. Ergas, S.; Sengupta, S.; Siegel, R.; Pandot, A.; Yao, Y.; Yuan, X. Performance of nitrogen-removing bioretention systems for control of agricultural runoff. J. Environ. Eng. 2010, 136, 1105-1112. [CrossRef]

44. Riffat, R. Fundamentals of Wastewater Treatment and Engineering; International Water Association CRC Press: London, UK, 2012.

45. Hsieh, C.-H.; Davis, A.P.; Needelman, B.A. Bioretention column studies of phosphorus removal from urban stormwater runoff. Water Environ. Res. 2007, 79, 177-184. [CrossRef] [PubMed]

46. Le Fevre, G.H.; Paus, K.H.; Natarajan, P.; Gulliver, J.S.; Novak, P.J.; Hozalski, R.M. Review of dissolved pollutants in urban storm water and their removal and fate in bioretention cells. J. Environ. Eng. 2015, 141, 04014050. [CrossRef]

47. Huber, M.; Welker, A.; Helmreich, B. Critical review of heavy metal pollution of traffic area runoff: Occurrence, influencing factors, and partitioning. Sci. Total Environ. 2016, 541, 895-919. [CrossRef] [PubMed]

48. Westerlund, C.; Viklander, M. Particles and associated metals in road runoff during snowmelt and rainfall. Sci. Total Environ. 2006, 362, 143-156. [CrossRef] [PubMed]

49. Bennasir, H.; Sridhar, S. Health hazards due to heavy metal poisoning and other factors in sea foods. Int. J. Pharm. Sci. Rev. Res. 2013, 18, 33-37.

50. Hrubá, F.; Strömberg, U.; Černá, M.; Chen, C.; Harari, F.; Harari, R.; Horvat, M.; Koppová, K.; Kos, A.; Krsková, A.; et al. Blood cadmium, mercury, and lead in children: An international comparison of cities in six european countries, and china, ecuador, and morocco. Environ. Int. 2012, 41, 29-34. [CrossRef] [PubMed]

51. Kayhanian, M.; Stransky, C.; Bay, S.; Lau, S.L.; Stenstrom, M.K. Toxicity of urban highway runoff with respect to storm duration. Sci. Total Environ. 2008, 389, 386-406. [CrossRef] [PubMed] 
52. Klaassen, C.D. Casarett and Doull's Toxicology: The Basic Science of Poisons; McGraw-Hill: New York, NY, USA, 2013; Volume 1236.

53. Li, H.; Davis, A.P. Water quality improvement through reductions of pollutant loads using bioretention. J. Environ. Eng. 2009, 135, 567-576. [CrossRef]

54. Hatt, B.E.; Fletcher, T.D.; Deletic, A. Hydrologic and pollutant removal performance of stormwater biofiltration systems at the field scale. J. Hydrol. 2009, 365, 310-321. [CrossRef]

55. Ross, S.M. Toxic Metals in Soil-Plant Systems; John Wiley and Sons Ltd.: Hoboken, NJ, USA, 1994.

56. Hatt, B.E.; Fletcher, T.D.; Deletic, A. Hydraulic and pollutant removal performance of fine media stormwater filtration systems. Environ. Sci. Technol. 2008, 42, 2535-2541. [CrossRef] [PubMed]

57. Gunawardena, J.; Ziyath, A.M.; Egodawatta, P.; Ayoko, G.A.; Goonetilleke, A. Sources and transport pathways of common heavy metals to urban road surfaces. Ecol. Eng. 2015, 77, 98-102. [CrossRef]

58. Australian and New Zealand Environment and Conservation Council; Agriculture and Resource Management Council of Australia and New Zealand. Australian and New Zealand Guidelines for Fresh and Marine Water Quality, Canberra; Australian and New Zealand Environment and Conservation Council: Canberra, Australia, 2000.

59. Davis, A.P. Field performance of bioretention: Water quality. Environ. Eng. Sci. 2007, 24, 1048-1064. [CrossRef]

60. Subramaniam, D.N.; Egodawatta, P.; Mather, P.; Rajapakse, J. Stabilization of stormwater biofilters: Impacts of wetting and drying phases and the addition of organic matter to filter media. Environ. Manag. 2015, 56, 630-642. [CrossRef] [PubMed]

61. Facility for Advancing Water Biofiltration. Guidelines for Filter Media in Biofiltration Systems (Version 3.01); Facility for Advancing Water Biofiltration: Melbourne, Australia, 2009; p. 8.

62. Duong, T.T.T.; Penfold, C.; Marschner, P. Differential effects of composts on properties of soils with different textures. Biol. Fertil. Soils 2012, 48, 699-707. [CrossRef]

(C) 2017 by the authors. Licensee MDPI, Basel, Switzerland. This article is an open access article distributed under the terms and conditions of the Creative Commons Attribution (CC BY) license (http:/ / creativecommons.org/licenses/by/4.0/). 